\title{
Agency Theory Approach to the Contracting between Lender and Borrower ${ }^{\#}$
}

\author{
Karel Janda*
}

\section{Introduction}

The purpose of this paper is to provide an introductory overview of the agency theory problems faced by the contracting parties in the credit market contracts. The paper is written in the form of literature survey. It emphasizes the main interesting results and provides a number of references to the original articles, surveys and textbooks where these briefly outlined results are treated in more detail.

Agency theory has been a very successful and active research area in economics, finance, management and related subjects all the time since the beginning of the seventies. The recent graduate textbook in economics written by two top theoreticians in this area Bolton and Dewatripont (2005) highlights that a number of founding contributors of agency theory - Ronald Coase, Herbert Simon, William Vickrey, James Mirrlees, George Akerlof, Joseph Stiglitz, Michal Spence - have been rewarded with the Nobel prize in economics. Therefore it is not a surprise to see in the Czech economic journals a growing number of papers using the agency theory approach to many problems in diverse subfields of economics and finance.

The agency theory was used to answer questions in economics of transition, which is one of profiling areas of Czech economic research. Janda $(2000,2003,2005)$ analyzes the problems of credit provision in transition economies in the classical agency theory setting of informational asymmetry between principal and agent. Turnovec (2000) deals with the hierarchical principal-agent problem in the analysis of the ownership structure, which is one of the principal topics of the economy of transition. The questions of ownership structure and privatization are analysed also by Kapička (2000), who concludes that both the right to cash-flow and the right to control should be transferred to the new owner during the privatization.

One the concerns of this paper is with the soft budget constraints, which are analysed by Janda (2002) and Knot and Vychodil (2005) in the context of optimal bankruptcy procedures design. The research interest of Knot and Vychodil (2005) in the law design is also shared by Bortel (2004), who deals with the economic analysis of law with a special emphasize on the issues of contracting and agency.

\# The work on this paper was supported by the Czech Science Foundation, grant number 402/06/0890.

* Doc. Ing. Karel Janda, Ph.D. - Transgas-RWE Group Chair in Economics; Department of Microeconomics and Mathematical Methods, Faculty of Social Sciences, Charles University, Opletalova 26, 11000 Praha 1, Czech Republic; Associate Professor; Department of Banking and Insurance, Faculty of Finance and Accounting, University of Economics, Prague, nám. W. Churchilla 4, 13067 Praha 3, Czech Republic; $<$ karel-janda@seznam.cz>. 
Besides these contributions dealing with the agency theory issues in the areas of economic of transition, ownership analysis and law and economics, we may identify other widely ranging applications of agency theory in the Czech economic journals. Thus Marek (2004) concentrates on agency theory in the corporate governance, which is one of the most traditional areas for the implementation of the agency theory. Marek (2004) is specially interested in the agency costs, in their influence on value of the firms and their measurement. He also mentions some interesting illustrations of agency cost theory in connection with privatization in transition economies. Direct application of agency theory to a specific field provides Krabec (2005) who identifies sources of principal-agent problems in the health care system.

Very classical field for the application of agency theory is the insurance, from where actually originates a lot of initial motivation and terminology used in the analysis of principal agent problems. The critical analysis of the mainstream agency theory approaches is provided by Daňhel (2002), who takes issues with some traditional informational assumptions used in the classical literature dealing with agency problems in insurance. An interesting alternative survival probability approach to insurance and principal-agent problem is provided by Hlaváček and Hlaváček (2006a, 2006b). The insurance is only one of the branches of financial services, which are successfully analysed with the use of agency theory. Another area is the analysis of the financial distress of the banks and the problems connected with the exit from the banking industry. These topics are the subject of papers by Frait (2002) or Janda (1994).

The principal-agent models of the agency theory may be roughly divided into three classes according to the nature of information asymmetry. First class are the models with ex-post asymmetric information. In these models the agent receives some private information after the signing of the contract between principal and himself. These models are known as moral hazard models. Second class are the models with ex-ante asymmetric information. In these models agent has private information already before the signing of the contract. These models are known as adverse selection models. Closely related is the third class of the models - signaling models. In these models the informed agent may reveal his private information through the signal which he sends to the principal.

In the rest of this paper we first briefly characterize these major classes of agency theory problems. Then we will turn to the application of agency theory to the contractual relationship between lenders and borrowers. We will discuss the problem of optimal form of credit contract, the adverse selection in credit market, the bankruptcy models and soft credit constraint literature. We will conclude with a few remarks on the informational assumption used in the agency theory literature dealing with credit markets.

\section{Principal-Agent Models}

\subsection{Moral Hazard}

The standard model of the moral hazard considers the situation with two decision makers: the principal and the agent. The principal hires the agent to perform some activity. The result of this activity is the monetary value $x$. The particular size of this monetary value depends both on randomly realized state of the world and the effort e of the agent. We denote by $p_{i}(e)$ the conditional probability of obtaining $x=x_{i}$ conditional on the level of exercised effort. The agent is paid by principal the amount $\mathrm{w}$. The utility of principal is given by a 
function $B(x-w)$. The additively separable utility of the agent is given by $U(w, e)=$ $u(w)-v(e)$, where $u(w)$ is utility from the payment $w$ and $v(e)$ is the disutility from the effort e. The reservation utility of the agent is $\underline{U}$. Unless otherwise mentioned, we assume all the usual regularity assumptions on the properties of all variables, parameters and functions in this and all following models.

The moral hazard aspect of this situation is captured by the assumption that the agent's choice of effort level $e$ is not observable by the principal. The principal designs the optimal contract such that he maximizes his expected utility subject to the participation and incentive compatibility constraints of the agent. Participation condition (sometimes labeled as individual rationality constraint) captures the idea, that the agent is willing to undertake the contract only if his expected utility from the contract is at least as high as his reservation utility $\underline{U}$. The incentive compatibility condition characterizes the self-enforcing nature of the contract, since the agent always chooses the level of the effort under which he expects to achieve the highest expected utility.

Formally, we write the optimization problem connected with this moral hazard model in the following way:

$$
\begin{aligned}
& \max _{\left[e_{1}\left\{w\left(x_{i}\right)\right\}_{i=1, \ldots, n}\right.} \sum_{i=1}^{n} p_{i}(e) B\left(x_{i}-w\left(x_{i}\right)\right), \\
& \text { s.t. } \sum_{i=1}^{n} p_{i}(e) u\left(w\left(x_{i}\right)\right)-v(e) \geq \underline{U}, \\
& e \in \arg \max _{\hat{e}}\left\{\sum_{i=1}^{n} p_{i}(\hat{e}) u\left(w\left(x_{i}\right)-v(\hat{e})\right)\right\},
\end{aligned}
$$

where the first restriction is the participation constraint and the second is the incentive compatibility constraint.

The moral hazard model which we consider here is dealing with so called ex-ante moral hazard. The term ex-ante in this context means that the moral hazard (choice of effort) happens before the random state of the world is realized. The wider class of moral hazard models also includes the situation with so called ex-post moral hazard. The term ex-post in this context means that the agent will be taking some action after the state of the nature is realized, revealed to the agent, but still unknown to the principal. We will specify the difference between ex-post and ex-ante moral hazard in more detail in the sections dealing with issues of moral hazard in the credit markets.

\subsection{Adverse Selection}

In this section we will retain the model of the preceding sections with some alterations. We will consider a risk neutral principal who is able to observe and verify the effort exercised by the agent. Therefore his utility function $B(x-w)$, which we used in the moral hazard model, will be replaced by $\Pi(e)=\sum_{i=1}^{n} p_{i}(e) x_{i}$.

Since the effort is verifiable, it may enter directly as an argument into the utility function of the principal. The ex-ante asymmetric information is captured by the assumption that the agent may be of two types, which are observationally undistinguishable for the principal. Principal knows that with probability $q$, the agent is of type $G$ and with 
probability $(1-q)$, the agent is of type $B$. The only difference between these two types is their disutility of effort. It is $v(e)$ for type $G$ and $k v(e)$ for type $B$, where $k>1$.

While the principal is not able to distinguish the observationally equivalent agents ex ante, he may be able to sort them through the offer of the contract. He offers the menu of two contracts $\left\{\left(e^{G}, w^{G}\right),\left(e^{B}, w^{B}\right)\right\}$ designed such, that type $G$ will choose the contract with the (effort, payment) combination $\left(e^{G}, w^{G}\right)$, while the type B will choose the $\left(e^{B}, w^{B}\right)$ offer from the menu. According to the revelation principle (Myerson (1979)), the menu of the contracts, which principal optimally offers to the agent, contains the same number of offered contracts as is the number of the types of agents and the contract are such, that each agent finds it optimal to choose the contract designed for his type. As long as these optimal contracts for different types of agents are different we call he equilibrium separating. If all the types prefer to receive the same contract, the pooling equilibrium obtains.

Formally, we write the optimization problem connected with this adverse selection model as follows:

$$
\begin{aligned}
& \max _{\left.\left[e^{G}, w^{G}\right)\left(e^{B}, w^{B}\right)\right]^{q}}\left[\Pi\left(e^{G}\right)-w^{G}\right]+(1-q) \cdot\left[\Pi\left(e^{B}\right)-w^{B}\right], \\
& \text { s.t. } u\left(w^{G}\right)-v\left(e^{G}\right) \geq \underline{U}, \\
& u\left(w^{B}\right)-k v\left(e^{B}\right) \geq \underline{U}, \\
& u\left(w^{G}\right)-v\left(e^{G}\right) \geq u\left(w^{B}\right)-v\left(e^{B}\right), \\
& u\left(w^{B}\right)-k v\left(e^{B}\right) \geq u\left(w^{G}\right)-k v\left(e^{G}\right),
\end{aligned}
$$

where the first two constraints are participation constraints and the last two are incentive compatibility constraints.

Sometimes it is possible for agents to engage in some activity which the principal may observe. Based on this observation, the principal may infer which type of activity is performed by which agent. Therefore the agents may in this way signal their types to the principal.

In the following section we will move from this general characterization of the principal agent models into the applications of these models to the relationship between lender and borrower.

\section{Lender-Borrower Models}

\subsection{Optimal Debt Contract}

One of the most fundamental applications of agency theory to the relationship between lender and borrower is the derivation of the optimal form of the lending contract. This problems is traditionally considered in the framework of costly state verification, which was introduced in path breaking article by Townsend (1979). The essence of the model is that the agent, who has no wealth of his own, borrows money from the principal to run a 
one-shot investment project. The outcome of the project is freely observed only by the agent. Therefore the agent is faced with a moral hazard problem. Should he announce the true outcome of the project or should be pretend that the outcome was lower? This means that this situation describes ex-post moral hazard, as opposed to the situation of ex-ante moral hazard, where the exercise of unverifiable effort by agent during the project realization may influence the result of the project.

As long as the principal has no mechanism available for rewarding or punishing the agent, the rational agent would always announce that the project failed. Therefore the agent would never repay back to principal. Rational principal would predict this outcome and he would never lent the money to the agent. In reality, it is usually possible for the principal to find out what the result of the project was. This stylized fact was formalized by Townsend (1979) in the concept of costly state verification. According to this assumption, the principal may incur fixed verification cost, which enable him to find out the exact true outcome of the project.

In this setup, the only source of social inefficiency is the verification cost. Therefore the optimal contract minimizes the expected verification cost. This is also the optimal contract achieved in the competitive market. The optimal contract which solves this problem is so called standard (or simple) debt contract. The name of this contract comes from the fact, that this contract closely resembles the usual simple debt contracts observed in the everyday life. The standard debt contract is characterized by its face value. This is the value, which should be repaid by the agent when the project is finished. As long as the agent repays this face value, the principal is satisfied and he does not need to verify the outcome of the project. If the agent does not repay the face value in full, the principal engages in the costly state verification. This could be understood as imposing the bankruptcy procedure on the agent. In the case the bankruptcy is imposed, the principal takes all results of the project and agent is left with nothing. Townsend (1979) proves that under this mechanism the agent has no incentive to lie, therefore he always truthfully announces the outcome of the project.

The standard costly state verification model is formulated under the assumptions that the principal is fully committed to his decisions and all strategies have to be deterministic. The assumption of deterministic strategies used to be considered quite restrictive. The original Townsend (1979) article already showed that allowing random verification decreases the expected verification cost. Border and Sobel (1987) and Mookherjee and Png (1989) allow for stochastic verification and the optimal contract features the repayment increasing as a function of the reported outcome of the project. Nevertheless the optimality of the adjusted simple debt contract was confirmed by Krasa and Villamil (2000) in the model which allows for stochastic strategies for both principal and agent. The crucial feature, which establishes optimality of adjusted simple debt contract is the missing commitment of principal and agent and the stipulation, that the agent keeps always some minimal part of the result of the project. Janda (2006) extends this approach and connects it with the literature dealing with absolute priority violations in bankruptcy proceedings.

The costly state verification model is besides the Townsend (1979) initial article closely connected with the papers by Gale and Hellwig (1985) and Williamson (1987), who applied the original general model to lending and borrowing contracts. As an another theoretical justification for simple debt contract used to be considered the model by Diamond (1984). In this model the outcomes of the projects are never observable by principal (this may happen if the verification cost would be prohibitively high or even infinite). Nevertheless even in this case it is possible to obtain the simple debt contract as an optimal fi- 
nancial contract if the principal may impose non pecuniary cost on the agent. These non pecuniary cost may be in the form of the loss of reputation or in the form of prison for debtors as in Welch (2002). The essential idea of this approach is that the agent is made indifferent between hiding the result of the project, which implies non pecuniary punishment, and truthfully revealing the outcome of the project. If the announced outcome of the project is lower than the agreed repayment, the agent is subjected to the non pecuniary punishment even in the case when he announces true outcome. This is because there is no way for principal to verify the agent's announcement. For the agent, the disutility of the punishment as a function of announced outcome is equal to (the negative of) the utility of the amount of money which would be computed as a difference between agreed repayment and the announced outcome.

For quite a long time it was considered that the Diamond (1984) approach provides essentially equivalent justification of the standard debt contract as the Townsend (1979) does. But Hellwig $(2000,2001)$ proves that the Townsend (1979) costly state verification models is substantially more robust explanation that the Diamond (1984) costly punishment model. Both models were originally formulated under the risk neutrality assumption. Hellwig $(2000,2001)$ shows that after the introduction of risk aversion, the costly state verification model still produces standard debt contract as an optimal solution to the principal-agent problem. But the costly punishment model as a justification of the standard debt contract does not survive the introduction of risk aversion.

\subsection{Lending with Adverse Selection}

The adverse selection is at the core of a wide literature dealing with overcoming this problem in lender-borrower relation. The most widely used class of these models is based on Besanko and Thakor (1987) who deal with the screening of the agents through the use of credit rationing and collateral. The screening terminology refer to the situation when the uninformed principal structures the credit contract so as to reveal different types of the agent, which are not directly observable. This is opposite to the signaling situation when the informed agent sends a signal to the principal to distinguish himself from other observationally equivalent agents.

As an illustration of adverse selection in the credit market we will present the following model taken from Janda (2004). We consider a risk neutral agent who wants to undertake a project. The project is either a failure, with return ${ }^{\sim} X$ normalized to $\sim=1$, or a success with the return $\sim X=X$. The project requires an investment $I \in(1, X)$. The agent can be either of type $L$ or type $H$. The probability of a success depends on the type of entrepreneur. It is $0<p_{L}<p_{H}<1$ for a "low" and a "high" type respectively. This is the only difference between these two types.

The agent has a collateralizable wealth $\mathrm{W}$ and he borrows the investment finance I from a risk neutral principal. The principal does not know the type of the borrower. He only knows that the proportion of type $L$ agents in the population is $\theta$. The principal also does not observe the return realization of the project. The principal learns the return realization only if he imposes bankruptcy upon a borrower and takes over the project. When the principal takes over the project or the outside collateral $C W$, his valuation of these is $\alpha^{\sim} X$ and $\alpha C$, respectively, where $0<\alpha<1$. 
The debt contract $(R, C)$ requires the agent to pay the amount of $R$ upon a completion of the project. If the agent does not pay $R$ the principal has a right to force the agent into a bankruptcy. Bankruptcy means that the principal takes over the project and the collateral $C$.

The principal's maximization problem is

$$
\begin{aligned}
\max _{\left(R_{L}, C_{L}, R_{H}, C_{H}\right)} M & =\theta U_{L}+(1-\theta) U_{H} \\
& =\theta\left[p_{L} \cdot\left(X-R_{L}\right)-\left(1-p_{L}\right) C_{L}\right]+(1-\theta) \cdot\left[p_{H} \cdot\left(X-R_{H}\right)-\left(1-p_{H}\right) \cdot C_{H}\right]
\end{aligned}
$$

subject to

$$
\begin{aligned}
& p_{i} \cdot\left(X-R_{i}\right)-\left(1-p_{i}\right) \cdot C_{i} \geq p_{i} \cdot\left(X-R_{j}\right)-\left(1-p_{i}\right) \cdot C_{j}, \\
& U_{i} \geq 0, \\
& p_{i} \cdot R_{i}+\left(1-p_{i}\right) \cdot \alpha \cdot\left(1+C_{i}\right)=1, \\
& 0 \leq C_{i} \leq W,
\end{aligned}
$$

where $\mathrm{i}, \mathrm{j} \in\{L, H\}$.

The equilibrium solution is given by the following separating contracts:

$$
\begin{aligned}
& C_{L}^{*}=0, \\
& R_{L}^{*}=\frac{I-\left(1-p_{L}\right) \cdot \alpha}{p_{L}},
\end{aligned}
$$

for a low type borrower and

$$
\begin{aligned}
C_{H}^{*} & =\frac{\left(p_{H}-p_{L}\right) \cdot(I-\alpha)}{p_{H} \cdot\left(1-p_{L}\right)-\alpha \cdot p_{L} \cdot\left(1-p_{H}\right)}, \\
R_{H}^{*} & =\frac{I-\left(1-p_{H}\right) \cdot \alpha \cdot\left(1+C_{H, N R}^{*}\right)}{p_{H}},
\end{aligned}
$$

for a high type borrower.

This means that the high (good) type of the agent distinguishes himself from the low (bad) type of the agent by posting the collateral $C^{*}{ }_{H}$. The intuition behind this result is the following. Since the high (good) type of agent has a lower probability of default, he is more willing to pledge a given level of collateral, because the same absolute level of collateral means for him lower expected transfer to the principal than would be the case for low (bad) type of agent with low probability of success.

Schmidt-Mohr (1997) uses richer set of possible instruments to solve the adverse selection problem. He considers size of the project, credit rationing, and collateral. Out of these instruments especially collateral received a lot of research attention. Richter (2006) provides an interesting agency theory explanation for the use of collateralized debt as debt with higher priority in bankruptcy proceedings. In his argument Richter (2006) outlines the agency theory model with two levels of moral hazard. Firstly he considers the incentive effect of debt financing on the management of firm. The threat of bankruptcy connected with 
the debt financing may serve as an incentive for management of the firm to work hard and to alleviate the moral hazard problem, where the manager is the agent and the owner is the principal. But as long as the lender has the same priority in the bankruptcy proceedings as other stake-holders (for example the employees or the providers of trade credit), he knows that after initiating the bankruptcy, he will get only a small part of his loan back. Therefore granting higher priority to the loans secured by collateral helps to overcome this moral hazard problem.

Another intriguing question is whether the higher collateral required from high quality than from the low quality borrower, as predicted by standard adverse selection models, is an empirically valid suggestion. The existence of screening function of collateral is supported by empirical study by Machauer and Weber (1998) and by empirical evidence and experiments reported by Capra, Fernandez, and Ramirez (2001). Opposite conclusions are reached in empirical studies of credit markets by Berger and Udell (1990 and 1995), Cressy and Toivanen (2001), and Klapper (2001). The empirical studies by Curry, Blalock and Cole (1991) and by Van Order and Schnare (1994) show that lenders often do report average loss rates on collateralized loans of more than 30 percent. This means that these loans are not fully collateralized from the point of view of the lender.

\subsection{Soft Budget Constraint and Bankruptcy}

The models which we considered in this paper up to now are essentially static models. Obviously there also exist a number of dynamic models of principal agent relation in the credit markets. Many of these models use the dynamic programing techniques. These recursive techniques are especially suitable to the analysis of the repeated moral hazard situation, like in Zhao (2004) or Monnet and Quintin (2005). Since the moral hazard situation refers to ex-post asymmetric information, it is quite natural to consider the situation of repeated provision of the loan. The behavior of the principal in each period $T$ may naturally depend on the behavior of the agent in the period $(T-1)$. For example the repayment of loan at $(T-1)$ may lead to the credit contract more favorable to the agent in the period $T$. The situation is somehow different in the case of repeated adverse selection. While with the moral hazard the agent may in any period engage or not engage in moral hazard behavior and information asymmetry is fully present in any period of the model, with adverse selection the full revelation of the type of the agent in period $(T-1)$ removes the information asymmetry for period $T$ and any subsequent periods.

Besides the models based on dynamic programming techniques there is a large literature dealing with the dynamic relationship between lender and borrower in the context of the soft budget constraint problem. This literature is especially relevant to the transition economies since it originated with the description of financing in centrally planed economies by Kornai (1979). Later on it was widely applied to the relationship between lenders and borrowers in transition economies, as documented by Kornai, Maskin and Roland (2003) and the references contained there.

The models of the soft and hard budget constraint in the transition economies came recently into prominence in relation to the pressing problem of bankruptcy design in the transition countries. Knot and Vychodil (2005) provide a general overview of the problem of optimal bankruptcy design. They especially emphasize the importance to distinguish clearly between ex-ante and ex-post efficiency. Soft bankruptcy laws usually perform quite well from the point of view of ex-post efficiency since they decrease the extent of excessive 
liquidation. But the power of agency theory lies primarily in the area of ex-ante efficiency considerations. The agency theory approach enables the modeler to clearly formulate negative incentive effects which the soft bankruptcy law may have on agent. Therefore the optimal design of bankruptcy laws have to take into consideration the trade-off between ex-ante and ex-post efficiency. Koleček (2005) also deals with this problem of optimal bankruptcy law design within the soft budget constraint framework of agency theory. His primary attention is directed toward the incentive effects of the interaction between bankruptcy laws and privatization decision. In the empirical part of his paper Kolecek (2005) shows, that there indeed exist statistically significant relations between the characteristics of the extent and method of privatization and the characteristics of bankruptcy laws in the transition countries.

In order to illustrate this brief discussion of the soft budget constraint as one of the applications of the agency theory to the credit markets, we will present here a simplified version of the soft budget constraint model of Janda (2004). We will consider the model of the previous section with added possibility for the principal to be soft on the agent. We will allow the principal to renegotiate the contract after the agent announces the failure of the project. If the project really failed, the principal would maximize his payoff by making a renegotiated offer of $(1, C)$.

We model this situation through the following game. There are many lenders and one borrower. Lenders compete by offering contracts $(R, C)$. Each lender can offer one pooling contract or he can offer two separating contracts, different for each type of borrower. If the borrower accepts one contract, the borrower and his lender play the following subgame.

In the first stage of this subgame the project is realized either as a success or as a failure. This realization is observed by the borrower but remains unknown to the lender.

In the second stage only the successful entrepreneurs can pay $R$ as $1<R \leq X$. Thus after observing failure outcome of the project, the borrower has to default. In the case of success the borrower has two choices. Either pay R or to claim that the project failed and default. The borrower can choose the mixed strategy according to which he defaults with probability $0 \leq d \leq 1$ and pays $R$ with probability $1-d$. In the case of repayment the game ends with payoffs $X-R$ for the borrower and $R-I$ for the lender. In the case of default the subgame continues to the third stage.

In the third stage after observing default the lender either imposes bankruptcy or offers a renegotiated contract $(1, C)$. The lender can randomize by imposing bankruptcy with the probability $0 \leq b \leq 1$. When bankruptcy happens, the lender takes over the project with the payoff being _ $(X+C)-I$ or $(1+C)-I$ according to the realization of the project. The borrower's payoff is $-C$. By renegotiating the contract the lender gets payoff $1+\alpha C-\mathrm{I}$ and the borrower gets $X-1-C$ if the project was a success or $-C$ if the project was a failure.

The subgame following the signing of contract can be solved using a perfect Bayesian equilibrium. If the lender never imposes bankruptcy after the agent's default, then the borrower always declares default. On the other hand, if the lender always imposes bankruptcy on defaulted entrepreneur, then the successful agent never defaults. This leaves a possibility of an equilibrium where both players use mixing strategy. However, if the probability of a successful outcome is relatively low or the costs of bankruptcy are relatively high, then the lender might impose bankruptcy only with small probability or not even bother to initiate bankruptcy proceedings because the expected gains from detecting false default may not compensate the costs of bankruptcy. In that case the successful agent in equilibrium would always default. However Janda (2004) shows that such equilibria would 
not satisfy the assumptions of the model. Therefore the unique equilibrium will indeed be in mixed strategies.

This means in particular that the agent faces the soft budget constraint in the sense that his default is not always automatically followed by hard bankruptcy proceeding. In this soft budget constraint equilibrium the agent with positive probability hides the result of his project (engages in a moral hazard behavior) and the principal forgives a part of the debt.

\section{Conclusions}

In this paper we have mentioned only a selected few problems of agency theory approach to the wide area of contracts between lenders and borrowers. We have shown that this is an active research area generating new insights and challenging older results, which were taken for granted for quite a long time. The topics of empirical relevance of the theoretical predictions, the dynamics of the credit contracts and the relation to law and institutional analysis are some of the most promising research directions in this field.

Also the validity of one of the major assumptions which we maintained throughout this paper may be reasonably questioned. This long standing assumption is the informational advantage of the agent over principal. It used to be generally accepted feature of agency theory models of credit market that the borrower has a better information than the lender. Nevertheless a number of models recently appeared which challenged this stylized fact. As examples we could mention the models by Inderst (2005), Manove, Padilla, and Pagano (2001), and Coelho, de Meza, and Reyniers (2004). This recently changed perception of classical informational assumptions could help to bridge gap between the results of the agency theory models and some empirically accepted opinions in the finance industry, which was pointed out by Danhel (2002) in the context of insurance. 


\section{References}

[1] BERGER, A. N. - UDELL, G. F. (1990): Collateral, loan quality, and bank risk. Journal of Monetary Economics, 1990, Vol. 25, No. 1, pp. 21-42.

[2] BERGER, A. N. - UDELL, G. F. (1995): Relationship lending and lines of credit in small firm finance. Journal of Business, 1995, Vol. 68, No. 3, pp. 351-381.

[3] BESANKO, D. - THAKOR, A. V. (1987): Collateral and rationing: Sorting equilibria in monopolistic and competitive credit markets. International Economic Review, 1987, Vol. 28, No. 3, pp. 671-689.

[4] BOLTON, P. - DEWATRIPONT M (2005): Contract theory. Cambridge, MIT Press, 2005.

[5] BORDER, K. C. - SOBEL, J. (1987): Samurai accountant: A theory of auditing and plunder. Review of Economic Studies, 1987, Vol. 54, No. 4, pp. 525-540.

[6] BORTEL, T. (2004): Ekonomická analýza práva (Economic Analysis of Law). Politická ekonomie, 2004, Vol. 52, No. 1, pp. 91-102.

[7] CAPRA, M. C. - FERNANDEZ, M. O. - RAMINEZ, I. (2001): The separating role of collateral requirements in credit markets with asymmetric information. Working Paper No. 23, Valencia, LINEEX, University of Valencia, 2001.

[8] COELHO, M. - de MEZA, D. - REYNIERS, D. (2004): Irrational exuberance, entrepreneurial finance and public policy. International Tax and Public Finance, 2004, Vol. 11, No. 4, pp. 391-417.

[9] CRESSY, R. - TOIVANEN, O. (2001): Is there adverse selection in the credit market? Venture Capital, 2001, Vol. 3, No. 3, pp. 215-238.

[10] CURRY, T. - BLALOCK, J. - COLE, R. A. (1991): Recoveries on distressed real estate and the relative efficiency of public versus private management. American Real Estate and Urban Economics Association Journal, 1991, Vol. 19, No. 4, pp. 495-515.

[11] DAŇHEL, J. (2002): K problému asymetrie informací v pojištovnictví (Observations regarding the Issue of Asymmetric Information in Insurance). Politická ekonomie, 2002, Vol. 50, No. 6, pp. 809-813.

[12] DIAMOND, D. W. (1984): Financial intermediation and delegated monitoring. Review of Economic Studies, 1984, Vol. 51, No. 3, pp. 393-414.

[13] FRAIT, J. (2002): Morální hazard a výstup z bankovního sektoru (Moral Hazard and Orderly Bank Exit). Finance a úvěr, 2002, Vol. 52, No. 2, pp. 102-104.

[14] GALE, D. - HELLWIG, M. (1985): Incentive-compatible debt contracts: The one period problem. Review of Economic Studies, 1985, Vol. 52, No. 4, pp. 647-663.

[15] HELLWIG, M. (2000): Financial intermediation with risk aversion. Review of Economic Studies, 2000, Vol. 67, No. 4, pp. 719-742.

[16] HELLWIG, M: (2001): Risk aversion and incentive compatibility with ex post information asymmetry. Economic Theory, 2001, Vol. 18, No. 2, pp. 415-438.

[17] HLAVÁČEK, J. - HLAVÁČEK, M. (2006a): Poptávková funkce na trhu s pojištěním: porovnání maximalizace paretovské pravděpodobnosti přežití s teorii EUT 
von-Neumanna a Morgensterna a s prospektovou teorii Kahnemana a Tverského, (Demand function in insurance industry: Comparison of maximization of Pareto's probability of survival with EUT theory and with the prospect theory of Kahneman and Tversky). Praha, Charles University, Faculty of Social Sciences, 2006.

[18] HLAVÁČEK, J. - HLAVÁČEK, M. (2006b): "Principal - agent" problem in the context of economic survival. Acta Oeconomica Pragensia, 2006, Vol. 14, No. 3, pp. 16-31.

[19] INDERST, R. (2005): Consumer lending when lenders are more sophisticated than households. Mimeo, December 2005.

[20] JANDA, K. (1994): Modelování rizika akciového portfolia (Modelling risks of share portfolio). Finance a úvěr, 1994, Vol. 44, No. 9, pp. 463-472.

[21] JANDA, K. (2000): Monopolistic credit market in the conditions of imperfect information. Prague Economic Papers, 2000, Vol. 9, No. 3, pp. 269-280.

[22] JANDA, K. (2002): Model konkurenčního úvěrového trhu v podmínkách nedokonalých informaci (A model of a competitive credit market in the conditions of imperfect information). Politická ekonomie, 2002, Vol. 50, No. 4, pp. 551-566.

[23] JANDA, K. (2003): Credit guarantees in a credit market with adverse selection. Prague Economic Papers, 2003, Vol. 12, No. 4, pp. 331-349.

[24] JANDA, K. (2004): Bankruptcy procedures with ex post moral hazard. Praha, Charles University, Faculty of Social Sciences Working paper No. 61, 2004.

[25] JANDA, K. (2005): The comparison of credit subsidies and guarantees in transition and post-transition economies. Ekonomický časopis, 2005, Vol. 53, No. 4, pp. 383-398.

[26] JANDA, K. (2006): Optimal deterministic debt contracts. Praha, Charles University, Faculty of Social Sciences Working paper, 2006.

[27] KAPIČKA, M. (2000): Jaké jsou náklady a výnosy privatizace? (What are the costs and benefits of privatization?) Politická ekonomie, 2002, Vol. 48, No. 2 , pp. 201-214.

[28] KLAPPER, L: (2001): The uniqueness of short-term collateralization. Working Paper 2544, World Bank, Washington, DC, February 2001.

[29] KNOT, O. - VYCHODIL, O: What drives the optimal bankruptcy law design. Finance a úvěr, 2005, Vol. 55, No. 3-4, pp. 110-123.

[30] KOLEČEK, L: (2005): Bankruptcy laws and privatization decision in transition countries. [on-line], Praha, Charles University, c2005, [cit. 3. 3. 2006], $<$ http://ies.fsv.cuni.cz/pub/CDS/workshop/kolecek.pdf $>$.

[31] KORNAI, J. (1979): Resource-constrained versus demand-constrained systems. Econometrica, 1979, Vol. 47, No. 4, pp. 801-819.

[32] KORNAI, J. - MASKIN, E. - ROLAND, G. (2003): Understanding the soft budget constraint. Journal of Economic Literature, 2003, Vol. 41, No. 4, pp. 1095-1136.

[33] KRABEC, T. (2005): Institucionální pohled na systémy zdravotní péče. (Health Care System-An Institutional View). Politická ekonomie, 2005, Vol. 53, No. 5, pp. 609-616. 
[34] KRASA, S. - VILLAMIL, A: P. (2000): Optimal contracts when enforcement is a decision variable. Econometrica, 2000, Vol. 68, No. 1, pp. 119-134.

[35] MACHAUER, A. - WEBER, M. (1998): Bank behavior based on internal credit ratings of borrowers. Journal of Banking and Finance, 1998, Vol. 22, No. 10-11, pp. $1355-1383$.

[36] MANOVE, M. - PADILLA, J. A. - PAGANO, M. (2001): Collateral vs. project screening: A model of lazy banks. RAND Journal of Economics, 2001, Vol. 32, No. 4, pp. 726-744.

[37] MAREK, P. (2004): Corporate governance and agency theory. Acta Oeconomica Pragensia, 2004, Vol. 12, No. 5, pp. 9-18.

[38] MONNET, C. - QUINTIN, E. (2005): Optimal contracts in a dynamic costly state verification model. Economic Theory, 2005, Vol. 26, No. 4, pp. 867-885.

[39] MOOKHERJEE, D. - PNG, I. (1989): Optimal auditing, insurance, and redistribution. Quarterly Journal of Economics, 1989, Vol. 104, No. 2, pp. 399-415.

[40] Myerson, R. B. (1979): Incentive compatibility and the bargaining problem. Econometrica, 1979, Vol. 47, No. 1, pp. 61-73.

[41] RICHTER, T. (2006): Two (further) possible explanations of the secured debt puzzle: A note. Praha, Charles University, Faculty of Social Sciences, Mimeo, 2006.

[42] SCHMIDT-MOHR, U. (1997): Rationing versus collateralization in competitive and monopolistic credit markets with asymmetric information. European Economic Review, 1997, Vol. 41, No. 7, pp. 1321-1342.

[43] TOWNSEND, R. M. (2000): Optimal contracts and competitive markets with costly state verification. Journal of Economic Theory, 1979, Vol. 21, No. 2, pp. 265-293.

[44] TURNOVEC, F. (2000): Who Are the Principals and Who Are the Agents? A Leontief - type Model of Ownership Structures. Finance a úvěr, 2000, Vol. 50, No. 11, pp. 648-650.

[45] VAN ORDER, R. - SCHNARE, A: B. (1994): Finding common ground. Secondary Mortgage Markets, 1994, Vol. 11, No. 1, pp. 15-19.

[46] WELCH, K. D. (2002): From debtor's prison to bankruptcy: The enforcement of optimal debt contracts. Chicago, University of Chicago, mimeo, 2002.

[47] WILLIAMSON, S. D. (1987): Costly monitoring, loan contracts and equilibrium credit rationing. Quarterly Journal of Economics, 1987, Vol. 102, No. 1, pp. 135-146.

[48] ZHAO, R. R. (2004): Repeated two-sided moral hazard. [on-line], Albany, State University of New York, c2004, [cit. 3. 3. 2006],

$<$ http://www.albany.edu/ rzhao/moral_hazard_zhao.pdf $>$. 


\title{
Smluvní vztah mezi věřitelem a dlužníkem z hlediska přístupu teorie zastoupení
}

\section{Karel Janda}

\begin{abstract}
Abstrakt
Článek poskytuje přehled několika vybraných témat zabývajících se aplikací teorie zastoupení na úvěrové smlouvy. Článek uvádí modely nákladného ověření stavu a modely optimálních úvěrových kontraktů za podmínek nákladného trestání a porovnává tyto modely s ohledem $\mathrm{k}$ jejich vypovídací hodnotě v situaci averse $\mathrm{k}$ riziku. Článek popisuje nepř́znivý výběr na úvěrových trzích a jeho řešení prostřednictvím jídelníčku prověřovacích kontraktů a diskutuje použití záruky jako prověřovacího kontraktu. Článek uvádí dynamický vztah mezi věřitelem a dlužníkem v modelu měkkého rozpočtového omezení v př́ípadě rozhodnutí o nesplacení a uvalení úpadku. Článek rovněž prezentuje alternativní předpoklady týkající se informačních asymetrií na úvěrových trzích. Pro všechna tato témata článek poskytuje množství odkazů na českou i mezinárodní ekonomickou literaturu.
\end{abstract}

Klíčová slova: principál; agent; smlouvy; úvěr; nepř́iznivý výběr; morální hazard.

\section{Agency Theory Approach to the Contracting between Lender and Borrower}

\begin{abstract}
The paper provides an overview of several selected topics dealing with application of agency theory to the credit contracts. The costly state verification and costly punishment models of optimal debt contracts are introduced and compared with respect to their performance in the situation characterized by risk aversion. Adverse selection in credit markets and its solution with a menu of screening contracts is described and the use of collateral as a screening instrument is discussed. The dynamic relationship between the lender and borrower is introduced in a soft budget constraint model of default and bankruptcy decisions. Alternative assumptions about informational asymmetries in credit markets are presented as well. For all these topics a number of references from Czech and international economic literature is provided.
\end{abstract}

Key words: principal; agent; contracts; credit; adverse selection; moral hazard.

JEL classification: C72, D82, G21. 